\title{
Commentary on Cefepime versus Cefoperazone/Sulbactam in Combination with Amikacin as Empirical Antibiotic Therapy in Febrile Neutropenia
}

\section{Introduction}

Febrile neutropenia (FN) remains an oncologic emergency since the advent of chemotherapy. Its significance was recognized in 1970s which led to empirical antibiotic use and resulted in major reduction of mortality from $50 \%$ to $26 \%$ due to neutropenic fever and sepsis. ${ }^{[1]}$ Since then, several international guidelines have defined use of first line and subsequent lines of antibiotics in settings of high risk FN..$^{[2-5]}$ For choice of first-line empirical antibiotic therapy (EAT), there is not one standard across all guidelines or institutes, many options exist directed by randomized controlled trails (RCTs) in different settings and guided by local antibiotic sensitivity data. We conducted a RCT comparing cefepime monotherapy versus cefoperazone/sulbactam with amikacin as EAT in FN at our center representative of a low resource setting with high prevalence of antibiotic resistance. ${ }^{[6]}$ Its been almost 2 years since the publication of results in May 2018, and we hereby review further developments in the same area and the current relevance of our study results.

\section{Study Background and Context}

The study was conducted from January 2015 to December 2016 at a Regional Cancer Centre in Southern India. Our previous practice was to use ceftazidime plus amikacin as initial EAT for FN. However, high incidence of resistance $(80 \%)$ to ceftazidime in our audit of blood culture data, prompted us to switch over to cefoperazone/ sulbactam, which had an overall lower resistance of around $40 \%$ (though limited published data were available on its use in FN setting). Aminoglycosides also had lower incidence of resistance (around $40 \%$ ) but drug-induced nephrotoxicity is the major concern. Cefepime (one of the recommended first-line antibiotics in guidelines) had not been used in our center and sensitivity pattern was not available from older studies. We assumed that as cefepime had never been used in our setting, it would generally have a low resistance pattern and would provide the advantage of monotherapy.

\section{Study Methodology and Results in Brief}

Episodes of high risk FN (except for patients undergoing induction therapy for acute myeloid leukemia [AML] or undergoing hematopoietic stem cell transplant) were randomized into one of the study arms; patients in Group A (experimental arm) received cefepime ( $2 \mathrm{~g}$ every $8 \mathrm{~h}$ for adults and $50 \mathrm{mg} / \mathrm{kg}$ every $8 \mathrm{~h}$ for children) and in Group B (standard arm) received cefoperazone/sulbactam ( $2 \mathrm{~g}$ every $8 \mathrm{~h}$ for adults and $50 \mathrm{mg} / \mathrm{kg}$ every $8 \mathrm{~h}$ for children) plus amikacin $15 \mathrm{mg} / \mathrm{kg}$ once daily. Clinical course of the FN episode was followed for response to treatment or occurrence of complications and treatment modifications. A total of 336 high-risk FN episodes in 175 patients were randomized equally into two arms (168 in each); and overall positive responses were similar in both the arms (53\% in each group), although low as compared to other studies $(60 \%-90 \%))^{[7,8]}$ We had a relatively high incidence of microbiologically documented infection (MDI) at $34 \%$, compared to $10 \%-30 \%$ in other studies ${ }^{[9,10]}$ and a significantly high incidence of MDR GNB (multidrug-resistant Gram-negative bacillus) at $51 \%$ of total MDI. In patients with negative responses, $88 \%$ FN episodes were successfully salvaged with subsequent second- and third-line antibiotics and antifungals. Mortality in the entire cohort was 7.5\% mostly infection related, a quarter of these deaths were due to progressive or refractory primary disease.

\section{Current Status in 2020 (of First-Line Empirical Antibiotic in Febrile Neutropenia)}

Several international guidelines that are periodically updated exists to guide the risk stratification and management of patients with FN in different settings. ${ }^{[2-5]}$ Last updated Infectious Disease Society of America $^{[2,5]}$ and European Conference on Infections in Leukemia $(\mathrm{ECIL})^{[3]}$ guidelines recommend monotherapy with cefepime, ceftazidime, carbapenem, piperacillin/ tazobactam, or, cefoperazone/sulbactam as first-line EAT in high risk FN patients. Several hundreds of randomized controlled trials (RCTs), retrospective, and prospective studies have been conducted comparing one antibiotic with the other as monotherapy or in combination, in high risk and low risk FN, in adult and pediatric patients with FN, and in settings of hematological and solid malignancies. In general, all are comparable and a center can choose their first line based on their local antibiogram and experience.

Tables 1 and 2 summarize some recent select RCTs comparing cefepime with other first line antibiotics and cefoperazone/sulbactam with other beta lactams or carbapenems, respectively. However, so far, ours has been the only study comparing these two antibiotics with each other. Majority of the studies conclude equal efficacy for the antibiotics compared. A recently published meta-analysis by Lan et al. in 2020, on efficacy and safety of cefoperazone-sulbactam in empiric therapy 


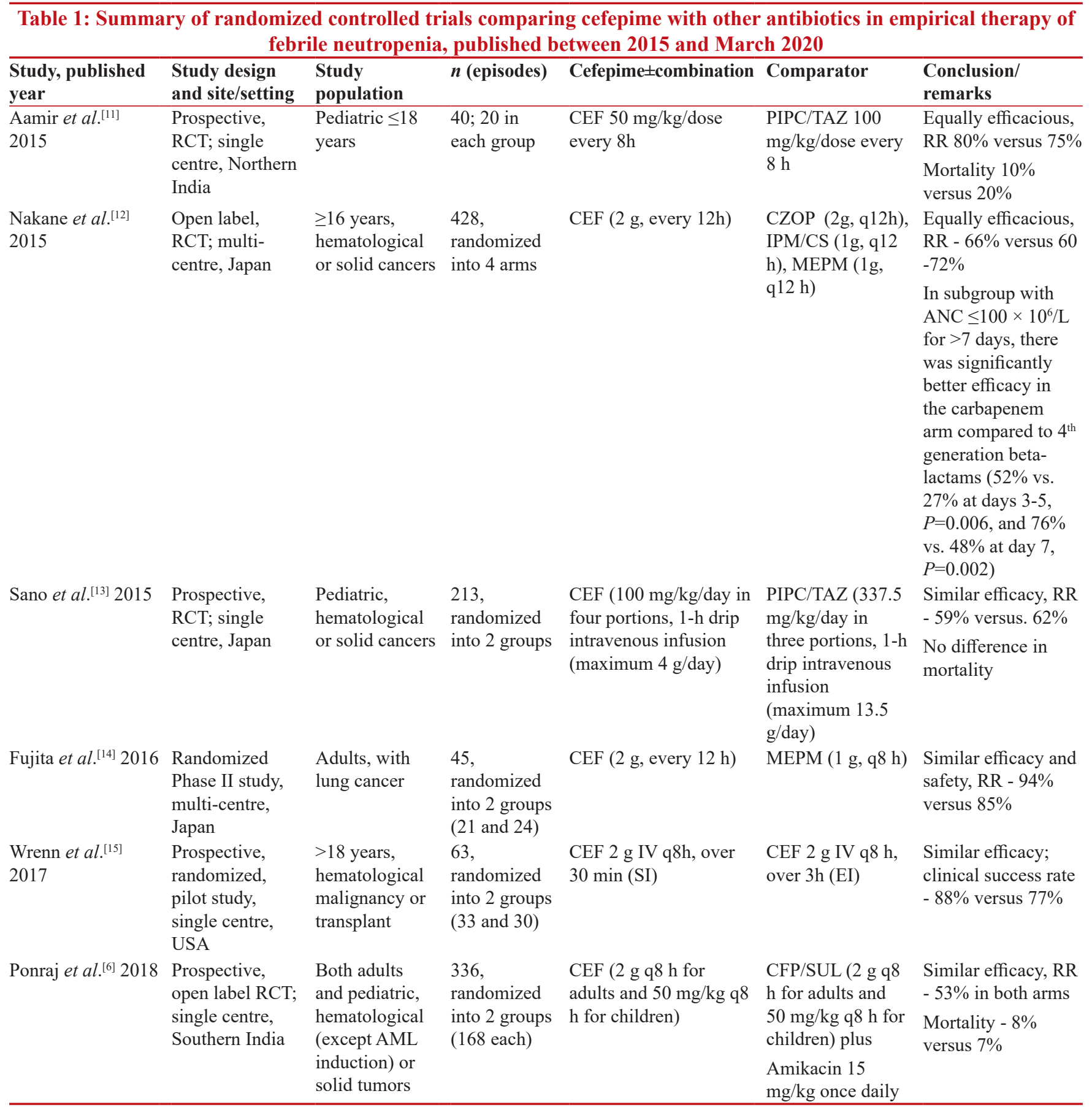

CEF - Cefepime; CFP/SUL - Cefoperazone-sulbactam; CZOP - Cefozopran; IPM/CS - Imipenem-cilastatin; MEPM - Meropenem; PIPC/TAZ - Piperacillin-tazobactam; RR - Response rate; RCT - Randomized controlled trials; SI - Standard infusion; EI - Extended infusion; AML - Acute myeloid leukemia

for FN, comprising of 10 RCTS including ours and one retrospective cohort study concluded that treatment success rate, risk of all-cause mortality, and common adverse events of cefoperazone-sulbactam are comparable to those of comparator drugs. ${ }^{[20]}$ Another meta-analysis by Andreatos et al. in 2017, with 32 trials reporting on 5724 patients, evaluating dose-dependent efficacy of cefepime in the empiric treatment of $\mathrm{FN}$, however, demonstrated increased mortality with cefepime compared to carbapenems, reduced efficacy in clinically documented infections and higher rates of toxicity-related treatment discontinuation. ${ }^{[21]}$ Authors concluded that although their findings required confirmation by future trials, the meta-analysis suggests that outcomes can be optimized by adjusting cefepime dosing recommendations and treatment indications, rather than discontinuing the use of this important antibiotic. In a meta-analysis by Kim et al. in 2010 , evaluating a possible signal of increased mortality 


\begin{tabular}{|c|c|c|c|c|c|c|}
\hline $\begin{array}{l}\text { Study, published } \\
\text { year }\end{array}$ & $\begin{array}{l}\text { Study design and } \\
\text { site/setting }\end{array}$ & $\begin{array}{l}\text { Study } \\
\text { population }\end{array}$ & $n$ (episodes) & $\begin{array}{l}\text { CFP/SUL based } \\
\text { regimen }\end{array}$ & Comparator & $\begin{array}{l}\text { Conclusion/ } \\
\text { remarks }\end{array}$ \\
\hline Demir et al..$^{[16]} 2011$ & $\begin{array}{l}\text { Prospective, open } \\
\text { label RCT; single } \\
\text { centre, Turkey }\end{array}$ & $\begin{array}{l}\geq 16 \text { years, } \\
\text { lymphoma or } \\
\text { solid cancers }\end{array}$ & $\begin{array}{l}208, \\
\text { randomized } \\
\text { into } 2 \text { arms } \\
(108 \text { each })\end{array}$ & $\begin{array}{l}\text { CFP/SUL (180 } \\
\text { mg/kg/day, q8h) }\end{array}$ & $\begin{array}{l}\text { Carbapenem } \\
\text { group (IPM, } 60 \\
\text { mg/kg/day, q8 h, } \\
\text { max } 4 \text { g; MEPM } \\
60 \mathrm{mg} / \mathrm{kg} / \text { day, } \\
\text { q } 8 \mathrm{~h}) .\end{array}$ & $\begin{array}{l}\text { Similar efficacy, RR } \\
-79 \% \text { versus } 81 \%\end{array}$ \\
\hline Karaman et al..$^{[17]} 2011$ & $\begin{array}{l}\text { Prospective, open } \\
\text { label RCT; single } \\
\text { centre, Turkey }\end{array}$ & $\begin{array}{l}\text { 1-18 years, } \\
\text { acute } \\
\text { leukemia, } \\
\text { lymphoma, or } \\
\text { solid tumors }\end{array}$ & $\begin{array}{l}102, \\
\text { randomized } \\
\text { into } 2 \text { arms ( } 50 \\
\text { and } 52)\end{array}$ & $\begin{array}{l}\text { CFP/SUL } 100 \text { mg/ } \\
\mathrm{kg} / \text { day, q8 h }\end{array}$ & $\begin{array}{l}\text { PIPC/TAZ } 360 \\
\mathrm{mg} / \mathrm{kg} / \text { day q } 8 \mathrm{~h}\end{array}$ & $\begin{array}{l}\text { Equally safe and } \\
\text { effective, RR - } 56 \% \\
\text { versus } 62 \%\end{array}$ \\
\hline $\begin{array}{l}\text { Demirkaya et al. }{ }^{[18]} \\
2013\end{array}$ & $\begin{array}{l}\text { Prospective, open } \\
\text { label RCT; single } \\
\text { centre, Turkey }\end{array}$ & $\begin{array}{l}0-18 \text { years, } \\
\text { lymphoma or } \\
\text { solid cancers }\end{array}$ & $\begin{array}{l}116, \\
\text { randomized } \\
\text { into } 2 \text { arms ( } 57 \\
\text { and 59) }\end{array}$ & $\begin{array}{l}\mathrm{CFP} / \mathrm{SUL} 100 \mathrm{mg} / \\
\mathrm{kg} / \text { day, q8 h plus } \\
\text { amikacin } 15 \mathrm{mg} / \\
\mathrm{kg} / \text { day q8 h }\end{array}$ & $\begin{array}{l}\mathrm{PIPC} / \mathrm{TAZ} 360 \\
\mathrm{mg} / \mathrm{kg} / \text { day q6 h } \\
\text { plus amikacin } 15 \\
\mathrm{mg} / \mathrm{kg} / \text { day q } 8 \mathrm{~h}\end{array}$ & $\begin{array}{l}\text { Equally safe and } \\
\text { effective, RR } \\
-52.6 \% \text { versus } \\
47.5 \%\end{array}$ \\
\hline Karaman et al..$^{[7]} 2013$ & $\begin{array}{l}\text { Retrospective } \\
\text { cohort study; } \\
\text { single centre, } \\
\text { Turkey }\end{array}$ & $\begin{array}{l}\text { Adult, low } \\
\text { risk FN }\end{array}$ & $\begin{array}{l}\text { 172, two arms } \\
(59 \text { and } 113)\end{array}$ & CFP/SUL $2 \mathrm{~g} \mathrm{q} 8 \mathrm{~h}$ & $\begin{array}{l}\text { PIPC/TAZ (4.5 g } \\
\text { q6 h) }\end{array}$ & $\begin{array}{l}\text { No difference in } \\
\text { efficacy, RR- } 64.5 \% \\
\text { versus } 73.5 \%\end{array}$ \\
\hline $\begin{array}{l}\text { Aynioglu et al. }{ }^{[19]} \\
2016\end{array}$ & $\begin{array}{l}\text { Randomized study; } \\
\text { single centre, } \\
\text { Turkey }\end{array}$ & $\begin{array}{l}\text { Adult, } \\
\text { hematological } \\
\text { malignancies }\end{array}$ & $\begin{array}{l}200, \\
\text { randomized } \\
\text { into } 2 \text { arms ( } 82 \\
\text { and } 118)\end{array}$ & CFP/SUL 2 g q8 h & $\begin{array}{l}\text { PIPC/TAZ (4.5 g } \\
\text { q6 h) }\end{array}$ & $\begin{array}{l}\text { Equally effective } \\
\text { and safe, RR- } 61 \% \\
\text { versus } 49 \%\end{array}$ \\
\hline Ponraj et al..$^{[6]} 2018$ & $\begin{array}{l}\text { Prospective, open } \\
\text { label RCT; single } \\
\text { centre, Southern } \\
\text { India }\end{array}$ & $\begin{array}{l}\text { Both adults } \\
\text { and pediatric, } \\
\text { hematological } \\
\text { (except AML } \\
\text { induction) or } \\
\text { solid tumors }\end{array}$ & $\begin{array}{l}336, \\
\text { randomized } \\
\text { into } 2 \text { groups } \\
\text { (168 each) }\end{array}$ & $\begin{array}{l}\text { CFP/SUL ( } 2 \text { g q } 8 \\
\mathrm{~h} \text { for adults and } \\
50 \mathrm{mg} / \mathrm{kg} \text { q } 8 \text { h for } \\
\text { children) plus } \\
\text { Amikacin } 15 \mathrm{mg} / \\
\mathrm{kg} \text { once daily }\end{array}$ & $\begin{array}{l}\mathrm{CEF}(2 \mathrm{~g} \mathrm{q} 8 \mathrm{~h} \\
\text { for adults and } 50 \\
\mathrm{mg} / \mathrm{kg} \mathrm{q} 8 \mathrm{~h} \text { for } \\
\text { children) }\end{array}$ & $\begin{array}{l}\text { Similar efficacy, } \\
\text { RR - } 53 \% \text { in both } \\
\text { arms } \\
\text { Mortality - } 8 \% \\
\text { versus } 7 \%\end{array}$ \\
\hline
\end{tabular}

CEF - Cefepime; CFP/SUL - Cefoperazone-sulbactam; IPM - Imipenem; MEPM - Meropenem; PIPC/TAZ - Piperacillin-tazobactam; $\mathrm{RR}$ - Response rate; AML - Acute myeloid leukemia; RCT - Randomized controlled trials

associated with cefepime use, authors concluded that in both trial-level and patient-level meta-analyses they did not identify a statistically significant increase in mortality among cefepime treated patients compared with those treated with other antibacterials. ${ }^{[22]}$

Our current practice is to use cefepime as first-line EAT in both adults and pediatric high risk FN requiring intravenous therapy with an average positive response of $60 \%-65 \%$. We recommend that institutes follow their local antibiotic sensitivity pattern in choosing their first-line therapy and cefepime is a valid option that can provide benefit of monotherapy.

\section{Status of Early Discontinuation of Empirical Antibiotics in Fever of Unknown Origin (FUO)}

The traditional approach since advent of EAT for FN had been to continue antibiotics till resolution of fever and till recovery of counts. However, recent reports especially in pediatric $\mathrm{FN}$ found that discontinuation of antibiotics before marrow recovery did not increase fatality due to bacterial infections. ${ }^{[23,24]}$ ECIL recommends that in select patients with FUO who have been hemodynamically stable since presentation and have been afebrile for $\geq 48 \mathrm{~h}$, EAT can be discontinued within $72 \mathrm{~h}$ irrespective of neutrophil recovery, however, these patients should be kept under close observation. ${ }^{[3]}$ Evidence for this discontinuation approach comes from limited studies, recent ones are summarized in Table 3.

In an open-label, randomized, controlled phase 4-trial on optimization of EAT in patients with hematological malignancies including transplant recipients with FN without etiological diagnosis, it was found safe to discontinue antibiotics after $72 \mathrm{~h}$ of apyrexia and clinical recovery irrespective of neutrophil count, without increasing the frequency of recurrent fever (recurrence rate $14 \%$ ), secondary infections, or mortality. ${ }^{[26]}$ In the prospective observational ANTIBIOSTOP study (2018), feasibility and safety of short-term antibiotic treatment in patients exhibiting FUO irrespective of their neutrophil count was evaluated and found to be safe with a response rate of $57 \%-59 \%$ in the two groups studied. ${ }^{[27]}$ In a meta-analysis by Stern et al., on early discontinuation 


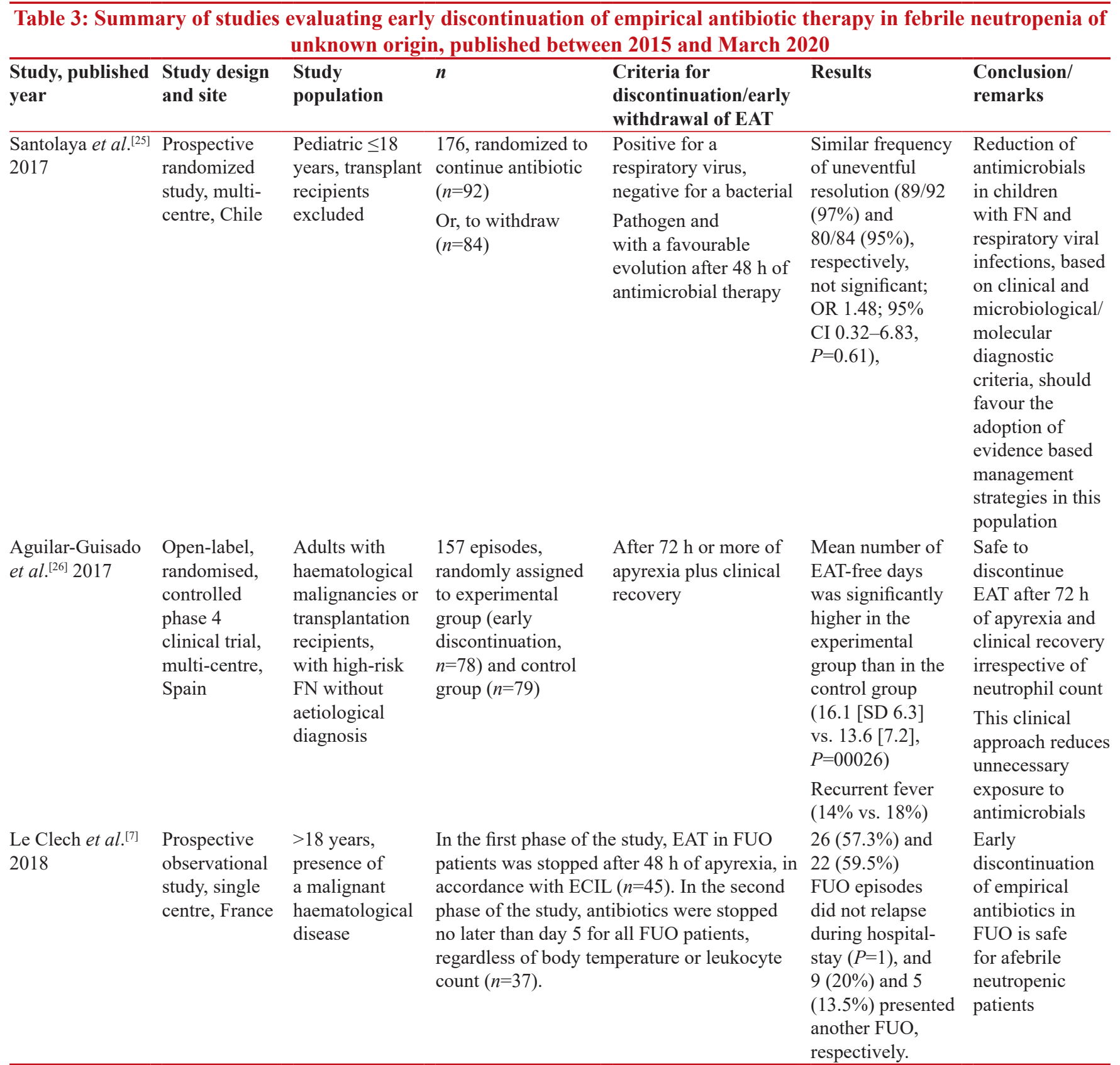

EAT - Empirical antibiotic therapy; FN - Febrile neutropenia; FUO - Fever of unknown origin; ECIL - European Conference on Infections in Leukemia; SD - Standard deviation

of antibiotics for FN, 8 RCTs comprising a total of 662 distinct FUO episodes in both adults and children were included. ${ }^{[28]}$ Studies had variable designs and criteria for discontinuation of antibiotics. No significant difference was seen between the short-antibiotic therapy arm and the long-antibiotic therapy arm for all-cause mortality, clinical failure rates, and other secondary outcomes. However, the author's concluded that the existing evidence have low certainty to make strong recommendation on the safety of antibiotic discontinuation before neutropenia resolution and well-designed, adequately powered RCTs are required to address this issue in the era of rising antibiotic resistance.
In our study, discontinuation of antibiotics was successful in $60 \%$ FUO episodes, and we continue to practice this approach in select cases of FUO to minimize antibiotic use and its associated collateral damage of augmenting antibiotic resistance.

\section{Challenges: Then and Now}

One of the most important challenges at our center and in other resource limited settings from developing countries is the high prevalence of multidrug-resistant gram-negative infections both in the community and in hospital acquired settings. In our study, MDI was 34\% of 
total episodes of FN, with a significantly high incidence of MDR GNB at $51 \%$ of total MDI. Our latest antibiogram in 2019 shows that various Gram-negative bacilli have $43 \%-85 \%$ sensitivity to cefoperazone-sulbactam, $45 \%$ to $95 \%$ sensitivity to amikacin, $40 \%-80 \%$ to cefepime, and $30 \%-76 \%$ for piperacillin-tazobactam. Resistance to carbapenems was seen in 5\%-15\% of Pseudomonas and Burkholderia species, while resistance rate was up to $55 \%$ for Klebsiella, Acinetobacter, and Escherichia coli. As there is growing resistance worldwide, newer antimicrobial agents especially against MDR GNB are very limited and pipeline of drug development is also very slow and parched, rational use of available antibiotics becomes essential for short-term patient-related outcomes and for long-term outcomes of containment of resistance.

Sending blood cultures and timely initiation of EAT at the onset of fever is essential for optimal outcome, however, full and consistent compliance to FN protocol is variable in different settings. Delayed presentation to health-care facility after onset of fever which can lead to a complicated clinical course is an added challenge in resource limited settings.

Most of the guidelines define use of empirical first line antibiotic and outline pathways for antibiotic modification at 48-72 $\mathrm{h}$ depending on the microbiological results and clinical course of patients. They also describe indications for the use of antifungals and antivirals. Nevertheless, the management of complicated FN beyond empirical treatment requires more of clinical experience and expertise and intensive supportive care.

Another challenge faced mostly in resource limited settings is implementation of infection control practices for both health-care workers $(\mathrm{HCW})$, patients and their care-givers because of lack of alertness and incentive among HCW and poor personal hygiene, lack of resources and awareness among patients and care-givers belonging to low socioeconomic background. Regular and systematic educational sessions for all cadres of HCW as well as for patients and care-givers and methods for the assessment of compliance are imperative to improve infection control.

\section{Way Forward}

The management of FN is a collective effort, requires collaboration with Departments of Microbiology, Pharmacology, Hospital Infection Control Committee, besides the treating clinical departments of Medical Oncology, Medicine, and Pediatrics. It needs continuous monitoring of infection control practices, institute's antibiotic sensitivity patterns over time, regular audits of clinical outcomes and revision of antibiotic policies if needed, and a robust antibiotic stewardship program. Finally, institutional policies for using appropriate antibiotics has to be tailored to (i) local sensitivity data, (ii) patient's risk factor for resistant infection, and (iii) patient's risk factors for a complicated clinical course. ${ }^{[3]}$ Early discontinuation of EAT is a promising approach in select cases of FUO.

FN is generally stratified as low or high risk in majority of guidelines and the standard approach in stable presentation is escalation. However, the subset of patients with prolonged and profound neutropenia as in AML induction and during salvage induction for relapsed leukemia should be considered as very high risk and may benefit from a de-escalation approach, though this indication and approach is not very clearly and separately defined in the literature. Furthermore, as stated in the ECIL guidelines, escalation and de-escalation approach with relevant indications can be a more appropriate method in the setting of high prevalence of MDR GNB. ${ }^{[3]}$ This will help in reducing high infection related mortality by avoiding initial inadequate EAT and by timely initiation of appropriate antibiotic covering resistant pathogen. However, physicians frequently hesitate to de-escalate appropriately and change a regimen that has already achieved clinical improvement; this has to be overcome by a good stewardship program. Novel biomarkers for early identification of resistant pathogens like rapid molecular diagnostic tests for sepsis using nucleic acid amplification techniques or host targeted technologies may guide the way forward. ${ }^{[29,30]}$

At our center, we have initiated a study evaluating role of sepsis bundle (with tailored antibiotic de-escalation approach based on clinical biomarkers) at the onset of very high risk FN during AML and relapsed leukemia induction. The application of sepsis bundle in FN has not been studied prospectively so far and we expect our results to be available by mid of 2021 .

\section{Financial support and sponsorship}

Nil.

Conflicts of interest

There are no conflicts of interest.

\section{Smita Kayal ${ }^{1}$, Ponraj Madasamy ${ }^{1}$, Jogamaya Pattnaik ${ }^{2}$}

${ }^{1}$ Department of Medical Oncology, Jawaharlal Institute of Postgraduate Medical Education and Research, Puducherry, India, ${ }^{2}$ Department of Medical Oncology, Kalinga Institute of Medical Sciences, Bhubaneswar,

Odisha, India

Address for correspondence: Dr. Smita Kayal, Department of Medical Oncology, Jawaharlal Institute of Postgraduate Medical Education and Research, Dhanvantari Nagar, Puducherry - 605 006, India. E-mail:kayalsmita@gmail.com

Submitted: 17-May-2020 Revised: 30-Jun-2020

Accepted: 03-Jul-2020

Published: 29-Aug-2020

\section{References}

1. Schimpff S, Satterlee W, Young VM, Serpick A. Empiric therapy with carbenicillin and gentamicin for febrile patients with cancer 
and granulocytopenia. N Engl J Med 1971;284:1061-5.

2. Freifeld AG, Bow EJ, Sepkowitz KA, Boeckh MJ, Ito JI, Mullen CA, et al. Clinical practice guideline for the use of antimicrobial agents in neutropenic patients with cancer: 2010 update by the infectious diseases society of america. Clin Infect Dis 2011;52:e56-93.

3. Averbuch D, Orasch C, Cordonnier C, Livermore DM, Mikulska M, Viscoli C, et al. European guidelines for empirical antibacterial therapy for febrile neutropenic patients in the era of growing resistance: summary of the $20114^{\text {th }}$ European Conference on Infections in Leukemia. Haematologica 2013;98:1826-35.

4. Klastersky J, de Naurois J, Rolston K, Rapoport B, Maschmeyer G, Aapro M, et al. Management of febrile neutropaenia: ESMO Clinical Practice Guidelines. Ann Oncol 2016;27:v111-v118.

5. Taplitz RA, Kennedy EB, Bow EJ, Crews J, Gleason C, Hawley DK, et al. Outpatient management of fever and neutropenia in adults treated for malignancy: American Society of Clinical Oncology and Infectious Diseases Society of America Clinical Practice Guideline Update. J Clin Oncol 2018;36:1443-53.

6. Ponraj M, Dubashi B, Harish BH, Kayal S, Cyriac SL, Pattnaik J, et al. Cefepime vs. cefoperazone/sulbactam in combination with amikacin as empirical antibiotic therapy in febrile neutropenia. Support Care Cancer 2018;26:3899-908.

7. Sipahi OR, Arda B, Nazli-Zeka A, Pullukcu H, Tasbakan M, Yamazhan T, et al. Piperacillin/tazobactam vs. cefoperazone/ sulbactam in adult low-risk febrile neutropenia cases. Int J Clin Pract 2014;68:230-5.

8. Tamura K, Matsuoka H, Tsukada J, Masuda M, Ikeda S, Matsuishi E, et al. Cefepime or carbapenem treatment for febrile neutropenia as a single agent is as effective as a combination of $4^{\text {th }}$-generation cephalosporin+aminoglycosides: Comparative study. Am J Hematol 2002;71:248-55.

9. Feld R, DePauw B, Berman S, Keating A, Ho W. Meropenem versus ceftazidime in the treatment of cancer patients with febrile neutropenia: A randomized, double-blind trial. J Clin Oncol 2000;18:3690-8.

10. Kwon KT, Cheong HS, Rhee JY, Wi YM, Ryu SY, Heo ST, et al. Panipenem versus cefepime as empirical monotherapy in adult cancer patients with febrile neutropenia: A prospective randomized trial. Jpn J Clin Oncol 2008;38:49-55.

11. Aamir M, Abrol P, Sharma D, Punia H. A clinical evaluation of efficacy and safety of cefepime monotherapy versus piperacillin-tazobactam in patients of paediatric age group with febrile neutropenia in a tertiary care centre of north India. Trop Doct 2016;46:142-8.

12. Nakane T, Tamura K, Hino M, Tamaki T, Yoshida I, Fukushima T, et al. Cefozopran, meropenem, or imipenem-cilastatin compared with cefepime as empirical therapy in febrile neutropenic adult patients: A multicenter prospective randomized trial. J Infect Chemother 2015;21:16-22.

13. Sano H, Kobayashi R, Suzuki D, Kishimoto K, Yasuda K, Kobayashi K. Comparison between piperacillin/tazobactam and cefepime monotherapies as an empirical therapy for febrile neutropenia in children with hematological and malignant disorders: A prospective, randomized study. Pediatr Blood Cancer 2015;62:356-8.

14. Fujita $M$, Matsumoto $T$, Inoue $Y$, Wataya $H$, Takayama $K$, Ishida $\mathrm{M}$, et al. The efficacy and safety of cefepime or meropenem in the treatment of febrile neutropenia in patients with lung cancer. A randomized phase II study. J Infect Chemother 2016;22:235-9.
15. Wrenn RH, Cluck D, Kennedy L, Ohl C, Williamson JC. Extended infusion compared to standard infusion cefepime as empiric treatment of febrile neutropenia. J Oncol Pharm Pract 2018;24:170-5.

16. Demir HA, Kutluk T, Ceyhan M, Yağcı-Küpeli B, Akyüz C, Cengiz $\mathrm{B}$, et al. Comparison of sulbactam-cefoperazone with carbapenems as empirical monotherapy for febrile neutropenic children with lymphoma and solid tumors. Pediatr Hematol Oncol 2011;28:299-310.

17. Karaman S, Vural S, Yildirmak Y, Emecen M, Erdem E, Kebudi R. Comparison of piperacillin tazobactam and cefoperazone sulbactam monotherapy in treatment of febrile neutropenia. Pediatr Blood Cancer 2012;58:579-83.

18. Demirkaya M, Celebi S, Sevinir B, Hacimustafaoglu M. Randomized comparison of piperacillin-tazobactam plus amikacin versus cefoperazone-sulbactam plus amikacin for management of febrile neutropenia in children with lymphoma and solid tumors. Pediatr Hematol Oncol 2013;30:141-8.

19. Aynioglu A, Mutlu B, Hacihanefioglu A. A comparison of the efficacy of piperacillin-tazobactam and cefoperazone-sulbactam therapies in the empirical treatment of patients with febrile neutropenia. Rev Esp Quimioter 2016;29:69-75.

20. Lan SH, Chang SP, Lai CC, Lu LC, Tang HJ. Efficacy and safety of cefoperazone-sulbactam in empiric therapy for febrile neutropenia: A systemic review and meta-analysis. Medicine (Baltimore) 2020;99:e19321.

21. Andreatos N, Flokas ME, Apostolopoulou A, Alevizakos M, Mylonakis E. The dose-dependent efficacy of cefepime in the empiric management of febrile neutropenia: A systematic review and meta-analysis. Open Forum Infect Dis 2017;4:ofx113.

22. Kim PW, Wu YT, Cooper C, Rochester G, Valappil T, Wang Y, et al. Meta-analysis of a possible signal of increased mortality associated with cefepime use. Clin Infect Dis 2010;51:381-9.

23. Santolaya ME, Villarroel M, Avendaño LF, Cofré J. Discontinuation of antimicrobial therapy for febrile, neutropenic children with cancer: a prospective study. Clin Infect Dis 1997;25:92-7.

24. Klaassen RJ, Allen U, Doyle JJ. Randomized placebo-controlled trial of oral antibiotics in pediatric oncology patients at low-risk with fever and neutropenia. J Pediatr Hematol Oncol 2000;22:405-11.

25. Santolaya ME, Alvarez AM, Acuña M, Avilés CL, Salgado C, Tordecilla J, et al. Efficacy and safety of withholding antimicrobial treatment in children with cancer, fever and neutropenia, with a demonstrated viral respiratory infection: A randomized clinical trial. Clin Microbiol Infect 2017;23:173-8.

26. Aguilar-Guisado M, Espigado I, Martín-Peña A, Gudiol C, Royo-Cebrecos C, Falantes J, et al. Optimisation of empirical antimicrobial therapy in patients with haematological malignancies and febrile neutropenia (How Long study): An open-label, randomised, controlled phase 4 trial. Lancet Haematol 2017;4:e573-83.

27. Le Clech L, Talarmin JP, Couturier MA, Ianotto JC, Nicol C, Le Calloch R, et al. Early discontinuation of empirical antibacterial therapy in febrile neutropenia: the ANTIBIOSTOP study. Infect Dis (Lond) 2018;50:539-49.

28. Stern A, Carrara E, Bitterman R, Yahav D, Leibovici L, Paul M. Early discontinuation of antibiotics for febrile neutropenia versus continuation until neutropenia resolution in people with cancer. Cochrane Database Syst Rev 2019;1:CD012184.

29. Sinha M, Jupe J, Mack H, Coleman TP, Lawrence SM, Fraley SI. Emerging technologies for molecular diagnosis of sepsis. Clin Microbiol Rev 2018;31:e00089-17. 
30. Al Jalbout $\mathrm{N}$, Troncoso $\mathrm{R}$ Jr., Evans JD, Rothman RE, Hinson JS. Biomarkers and molecular diagnostics for early detection and targeted management of sepsis and septic shock in the emergency department. J Appl Lab Med 2019;3:724-9.
This is an open access journal, and articles are distributed under the terms of the Creative Commons Attribution-NonCommercial-ShareAlike 4.0 License, which allows others to remix, tweak, and build upon the work non-commercially, as long as appropriate credit is given and the new creations are licensed under the identical terms.

\begin{tabular}{|l|l|}
\hline \multicolumn{2}{|c|}{ Access this article online } \\
\hline Quick Response Code: & Website: \\
& www.ijmpo.org \\
\cline { 2 - 2 } & DOI: \\
& 10.4103/ijmpo.ijmpo_237_20 \\
\hline
\end{tabular}

How to cite this article: Kayal S, Madasamy P, Pattnaik J. Commentary on cefepime versus cefoperazone/sulbactam in combination with amikacin as empirical antibiotic therapy in febrile neutropenia. Indian J Med Paediatr Oncol 2020;41:570-6. 